\title{
Effect of Quality of Logistics Services and Consumer Safety on Purchasing Decisions in Bhinneka E-Commerce
}

\author{
Kus Tri Dianavera*, Toto Aminoto \\ Department of Management \\ Sekolah Tinggi Ilmu Ekonomi Indonesia Jakarta \\ Jakarta, Indonesia \\ *dianavera@stei.ac.id
}

\begin{abstract}
This study aims to prove whether the quality of logistics services and consumer safety influence purchasing decisions on E-Commerce Bhinneka. The research method used is a quantitative method. Data obtained by distributing questionnaires to residents in Jatisari, Bekasi City. The sampling method used was accidental and purposive sampling. Data were analysed using Structural Equation Modelling. The results showed that the quality of logistics services had a significant effect on purchasing decisions, while consumer safety had no significant effect on purchasing decisions on Bhinneka $E$ commerce.
\end{abstract}

Keywords: quality of logistics services, consumer safety, purchasing decisions on E-Commerce

\section{INTRODUCTION}

E-commerce is a trade in goods and services through electronic devices or similar to assist consumers in obtaining goods and services [1]. With e-commerce, we can access and find all product information worldwide quickly and easily. Currently, the development of e-commerce in Indonesia is very rapid along with technological developments and lifestyles.

In online transaction security also plays an important role. Security is the ability of e-commerce companies to control and maintain the security of data transactions. This security includes the ability of the website to prevent data modification, the security of no agreement being broken, the security of the confidentiality of messages and the security that the site functions for transactions. As we know the online world is full of hackers so consumers really demand its security. If in terms of safety guaranteed, the decision of a consumer to buy a product will be even higher [2].

Service Quality is a dynamic condition that affects products, services, people, processes and environments that meet or exceed expectations. So the definition of service quality can be interpreted as an effort to meet the needs and desires of consumers and the accuracy of its delivery in balancing consumer expectations [3].
Measurement of Logistic Service Quality is divided into 4 dimensions [4], namely:

- Timeliness discusses whether the order arrived at the customer's location in accordance with the promised time. Timeliness also refers to the time taken between placing an order and receiving it by the customer.

- Accuracy of Order refers to how close the shipment is to the customer's order. This includes the accuracy of the types of goods on the order as well as the accuracy of the number of goods.

- Quality of Information refers to the customer's perception of information provided by the company regarding products that can be selected by the customer.

- Quality of Contact Personnel refers to customer orientation to contact people from the company's logistics department. Specifically, customers see whether customer service staff are knowledgeable, sympathetic to customer situations, and help customers solve customer problems.

There are six safety indicators [5]:

- Integrity, namely the ability of the Bhinneka site to prevent unauthorized data modification.

- Nonrepudiation, namely the ability of the Bhinneka site to ensure that one party does not renege on the agreement after a transaction.

- Authentication, namely the ability of the Bhinneka site to identify a person's identity.

- Confidentiality, namely the ability of the Bhinneka site to guarantee the confidentiality of messages and data available.

- Privacy is the ability of the Bhinneka site to provide control of personal information to users. 
value of the standardized loading factor must be at least above 0.5 . The $t$ value and the standardized loading factor value are generated by running the Lisrel program through the path. While the reliability value uses the Cronbach's Alpha coefficient. If the reliable value is above 0.7 , it can be said that the data is reliable.

The results of the validity test for each question item on the variables namely Logistics service quality, security and purchasing decisions show values above 0.5 so that it is stated

The reliability test results showed that the Alpha Cronbach's coefficient values questions for the elements of service quality 0.744 , security 0.770 and purchasing decisions 0.816 , all above 0.7 as well as the overall test questionnaire showed a coefficient value above 0.7 . Thus it was concluded that both in each construct and as a whole the questionnaire was reliable.

\section{B. Full Model-Structural Equation Analysis}

Analysis of the data used in this study is the Structural Equation Model (SEM). However, several stages of analysis will be carried out to form the best model. The input data used in this study is the variance/covariance matrix. Covariance matrices are judged to have the advantage of providing valid comparisons between populations or different samples, which is sometimes not possible using a correlation matrix model.

The estimation model used is the maximum likelihood estimation. Before testing the full model, testing will be carried out in stages, namely the estimation of the measurement model with the confirmatory factor analysis technique.

Analysis of the results of data processing at the full SEM model stage is carried out by conducting a suitability test and a statistical test. The results of data processing for the full SEM model analysis are shown in Figure 1. analysis unit of the population of at least 21 years of age in the Jatisari Jatiasih sub-district, Bekasi City with a sample size of 200.

The analysis used in this study was a quantitative analysis of a set of data that is expressed in figures as a result of observation or collection. A multiple linear regression model (multiple linear regression method) was used in the analysis. The model used in this study is the causality model and to test the hypotheses proposed in this study, the analysis technique used is SEM (Structural Equation Modelling) which is operated through the LISREL program.

The process of quantitative analysis was performed using statistical calculations as follows: Test Validity and Reliability, Full Model-Structural Equation Analysis (previously estimation of measurement model with confirmatory factor analysis technique), and Hypothesis Testing.

\section{RESULTS AND DISCUSSION}

\section{A. Validity Test and Reliability Test}

Validity testing is done by looking at the value of the standardized loading factor and the value of $t$ of each generated. The resulting t value must be above 1.96 . While the

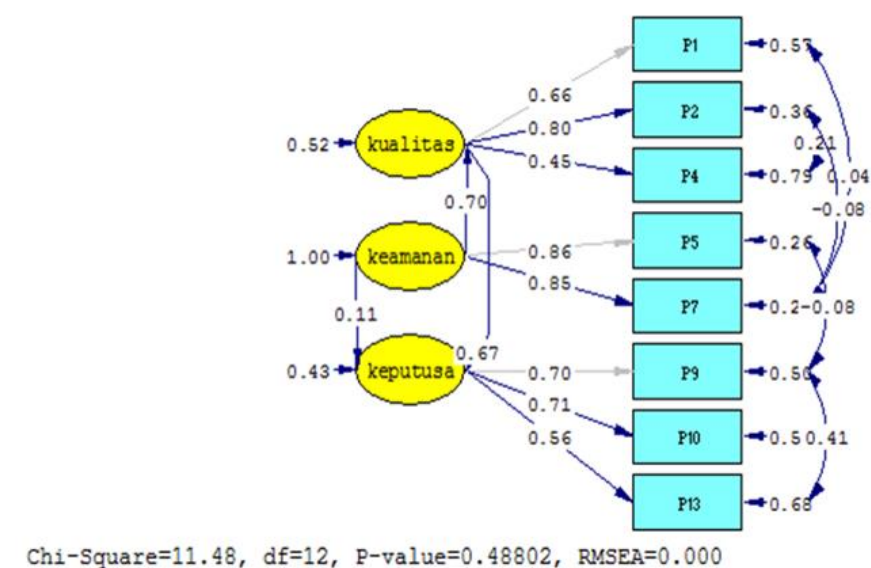

Fig. 1. Full model test results.

Generally, based on Figure 1 above, the question indicators for the construct of service quality are 3 questions. The results show that $\mathrm{p} 4$ (time limit) apparently does not contribute strongly to the quality construct. While those that contributed strongly were $\mathrm{p} 2$ (information quality) of 0.80 and 
that there is a positive influence between the quality of purchasing decisions.

3) Security hypothesis testing of purchasing decisions: The estimated parameter of the relationship between security and purchasing decisions obtained by $\mathrm{t}$ is 0.74 . While $\mathrm{t}$ table $=$ 1.972. Thus $t$ arithmetic < t table. So it can be concluded that security has no positive effect on purchasing decisions.

\section{CONCLUSION}

The results of the analysis of data processing show that the construct used to form a research model, in the confirmatory factor analysis process has met the established goodness of fit criteria. This is because several criteria have been met. The results of Figure 1 above have passed the modification process indicated by the program. The calculation results show that the highest correlation is between the qualities of logistics services to security that is equal to 0.7 . While the lowest correlation between safeties and purchasing decisions is 0.11 .

In the full model SEM analysis process has met the specified goodness of fit criteria. Chi-square value calculated is smaller than the chi-square cut off value of $21.03 \geq 11.48$. Other measures of goodness of fit also indicate good conditions. To get a good model, we will first examine the problem of deviations from the SEM assumptions. The values above have been adjusted to the modification indices requested by the program.

\section{Hypothesis Test}

The results of SEM analysis as hypothesis testing steps are as follows:

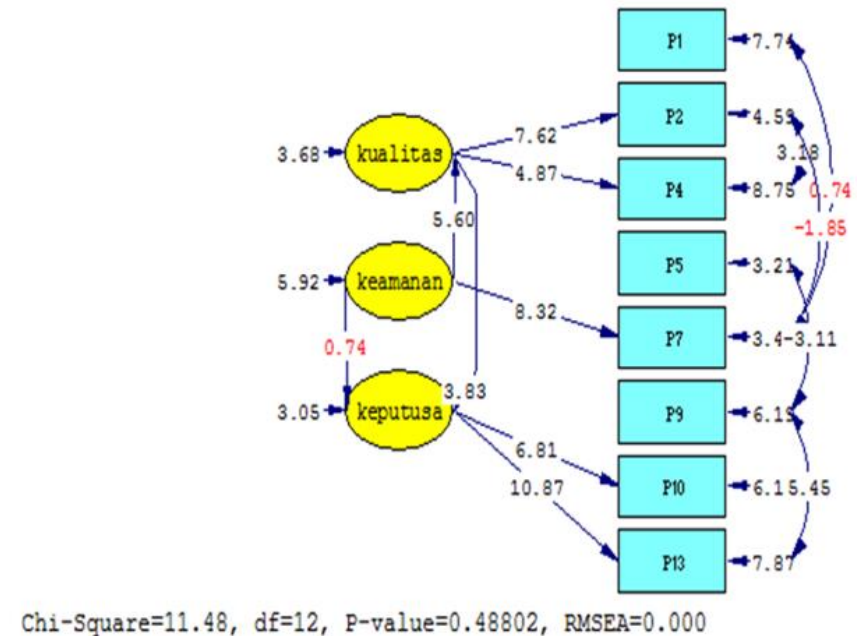

Fig. 2. Hypothesis testing results.

1) Hypothesis testing of service quality to security: The results of the calculation of the influence of service quality on security obtained $t$ arithmetic of 5.60. While $t$ table $=1.972$. Thus $t$ count $>t$ table. So it can be concluded that the quality of service has a positive effect on security.

2) Quality hypothesis testing of purchasing decisions: The results of the calculation of the relationship between quality and purchasing decisions obtained $\mathrm{t}$ count of 3.83. While $\mathrm{t}$ table $=1.972$. Thus $\mathrm{t}$ count $>\mathrm{t}$ table. So it can be concluded
The results showed that questions relating to the construct of service quality showed that questions related to the deadline (p4) apparently did not contribute strongly to the construct of quality. This is because online shoppers have felt from the start that when making a purchase it will definitely take longer than a regular purchase. Thus the buyer can understand if the shipping process will experience a slight delay. While the strong contributor is p2 (information quality), it is believed that buyers feel confident that the information provided by the Bhineka website is considered to be true because it is accompanied by an image of the item to be purchased. And p1 (order accuracy) contribution also affects the construct of service quality. This is because when ordering orders immediately invoice goods ordered so that the possibility of misses is very small.

Question indicators for security construct as much as 2 all contributed strongly to the availability of goods (p5) and privacy (p7). This is because the buyer believes the availability of goods is clearly informed on the site so that when the buyer orders the goods, he is sure that the goods he ordered must be available in addition to that privacy is also maintained because when an order is made, the buyer login with a certain password.

Question indicators for the purchase decision construct are 3 questions. The results show that all of them contribute to the construct of purchasing decisions. While those who contributed strongly were p10 (people who influence). The results show that when people buy something more influenced by others than their own initiative. Questions relating to p13 (User) have smaller contributions. This is mostly buying goods not used alone.

Based on the results of hypothesis testing it can be concluded that the quality of service has a positive effect on decisions. But security has no positive effect on purchasing decisions.

\section{REFERENCES}

[1] L. Jayanthi, "Role of E-Commerce In Modern Business," SRM Management Digest, vol. 6, no. 1, 2018.

[2] F.V. Sudjatmika, "Pengaruh Harga, ulasan produk, kemudahan, dan keamanan terhadap keputusan pembelian secara online di Tokopedia. Com," Agora, vol. 5, no. 1, 2017.

[3] A. Meesala and J. Paul, "Service quality, consumer satisfaction and loyalty in hospitals: Thinking for the future," Journal of Retailing and Consumer Services, vol. 40, pp. 261-269, 2018.

[4] A. Awasthi, R. Sayyadi, and A. Khabbazian, "A combined approach integrating gap analysis, QFD and AHP for improving logistics service quality". International Journal of Logistics Systems and Management, vol. 29, no. 2, pp.190-214, 2018 security. Quality has a positive influence on purchasing 
[7] C. Prentice and P.M. Singh, "The influence of risk perception and brand image on airline passengers' travel behaviours," CAUTHE 2018: Get Smart: Paradoxes and Possibilities in Tourism, Hospitality and Events Education and Research, pp. 600, 2018. terhadap Minat Beli di situs Online (Studi Kasus pengunjung situs Lazada di Jakarta Timur)," Jurnal Manajemen, vol. 9, no. 1, pp. 46-57, 2018.

[6] P. Kotler and G.M. Armstrong, Marketing Mix: Selected Chapters From: Principles of Marketing, Philip Kotler and Gary Armstrong. New Jersey: Pearson 2018 